\title{
Taxonomic status of Cyathostoma nematodes (Nematoda: Syngaminae) parasitizing respiratory tracts of birds of prey and owls in Europe and North America: how many species are there?
}

\author{
G. KANAREK ${ }^{1, *}$, G. ZALEŚNY², J. SITKO ${ }^{3}$, A. I. BLANCO ${ }^{4}$ \\ ${ }^{1}$ Ornithological Station, Museum and Institute of Zoology Polish Academy of Sciences, Nadwiślańska 108, 80-680 Gdańsk, Poland, \\ `E-mail: kanarek@miiz.waw.pl; " Institute of Biology, Wrockaw University of Environmental and Life Sciences, Kożuchowska 5b, \\ 51-631Wroclaw, Poland, E-mail: grzegorz.zalesny@up.wroc.pl; ${ }^{3}$ Comenius Museum, Horní nám. 7, 75011 Přerov, \\ Czech Republic, E-mail: j.sitko@email.cz; ${ }^{4}$ Department of Pathobiology and Veterinary Science, University of Connecticut, Storrs, \\ Connecticut, USA, E-mail: anapathologist@gmail.com
}

Article info

Received May 14, 2015

Accepted September 30, 2015

\begin{abstract}
Summary
So far, the identity of Cyathostoma (Hovorkonema) nematodes collected from respiratory tracts of birds of prey (Accipitriformes, Falconiformes) and owls (Strigiformes) in Europe and North America is extremely inconsistent. Our results, based on analyses of ITS-2 sequences suggest that the $\mathrm{Cy}$ athostoma (Hovorkonema) nematodes found in the birds of prey and owls from Central Europe and North America probably belong to the same species , C. (Hovorkonema) americana Chapin, 1925. We are convinced, that described in recent literature high ITS-2 divergence among C. (Hovorkonema) nematodes collected from Europe, has occurred as a result of invalid synonimisation of some $C$. (Hovorkonema) species. In our opinion C. (Hovorkonema) americana (typically parasites of tracheae and air sacs of raptors) and C. (Hovorkonema) variegatum (Creplin, 1849) (typically parasites of tracheae of cranes and storks) are valid molecular and morphologically distinct species.

Keywords: Nematoda; Syngamidae; Cyathostoma (Hovorkonema); birds of prey; owls; ITS-2
\end{abstract}

\section{Introduction}

The subfamily Syngaminae Baylis \& Daubney, 1926 comprising parasites of respiratory tracts of birds (genera Boydinema, $\mathrm{Cy}$ athostoma, Syngamus) and mammals (genera Mammomonogamus and Rodentogamus). The largest (more than 20 species) is genus Cyathostoma, a taxa with a long and confused history. This genus was established by Blanchard (1849) for Cyathostoma lari, species described from the orbital cavity of the black-headed gull Chroicephalus ridibundus. Over a period of years, the validity of Cyathostoma was widely discussed: some authors recognized Cyathostoma as a synonym of Syngamus (e.g., Skryabin, 1915; Yamaguti, 1961), but others accepted this taxon as correct. T However, the definition and taxonomic position of Cyathostoma has been modified several times in relation to different evaluation of morphological features (e.g., Chapin, 1925; Ryzhikov, 1949; Hovorka \& Macko, 1959; Turemuratov, 1963; Ryzhikov, 1967; Lengy,
1969; Ali, 1970; Baruš \& Tenora, 1972). In the most recent system of Syngaminae proposed by Lichtenfels (1980) the genus Cyathostoma is divided into two subgenera in relation to the structure of copulatory bursa and spiculae length: Cyathostoma (Cyathostoma) (Blanchard, 1849), in which the dorsal ray extends beyond the end of the copulatory bursa to form characteristic thorn-like projections and spicules that measure $0.08-0.4 \mathrm{~mm}$, and Cyathostoma (Hovorkonema) Turemuratov, 1963 in which the dorsal ray does not extend beyond the end of the copulatory bursa and spicules measure $0.45-0.8 \mathrm{~mm}$. In the systems of Syngamidae created by Ryzhikov (1967) and Baruš and Tenora (1972) Cyathostoma and Hovorkonema are treated as independent genera.

Occurrence of Cyathostoma nematodes have been reported in a variety species of birds from several orders (Kanarek et al., 2013). Indisputably, Cyathostoma infection has great significance as a potential pathological factor in poultry production and many aspects of conservation of vulnerable or endangered avian species (for details 
see e.g., Fernando \& Barta, 2008 and references therein). Usually, occurrence of these nematodes is subclinical, but heavy infections are often associated with bacterial and/or fungal infections. Several reports of morbidity and mortality of birds, particularly birds of prey and owls caused by infection of Cyathostoma are available (e.g., Hunter et al., 1993; Lavoie et al., 1999; Krone et al., 2007; Vaughan-Higgins et al., 2013). Thus, understanding of all aspects of ecology and taxonomy of these syngamid nematodes has great practical importance for veterinary and conservation reasons in general. Currently, four species of these nematodes have been recorded from birds of prey (Accipitriformes, Falconiformes) and owls (Strigiformes): C. (Hovorkonema) americana Chapin, 1925; C. (Hovorkonema) brodskii Sultanov, 1946; C. (Hovorkonema) variegatum (Creplin, 1849) and C. (Cyathostoma) lari Blanchard, 1849. Moreover, several reports on the occurrence of Cyathostoma nematodes determined only to the genus level in birds of prey and owls are available (e.g., Mumcuoglu \& Müller, 1974; Hunter et al.,1993; Lavoie et al., 1999; Vaughan-Higgins et al., 2013). Among the mentioned species, $C$. (Cyathostoma) lari is a typical parasite of gulls, only occasionally reported from birds of prey (Simpson \& Harris, 1992). However, when delimitation of $C$. (Cyathostoma) lari from other mentioned $C$. (Hovorkonema) species recorded in birds of prey and owls regarding characteristic habitat (C. (Cyathostoma) lari occurred in nasal and orbital cavities, while other species are detected in tracheae, bronchii and air sacs) and morphological features typical for nominal subgenus Cyathostoma (structure of copulatory bursa, spiculae length) are rather trivial, thus morphological boundaries between closely related $C$. (Hovorkonema) americana, C. (Hovorkonema) brodskii and C. (Hovorkonema) variegatum are still contentious. Moreover, several revisions and doubtful synonimisations (e.g., Vogel, 1928; Ali, 1970; Ryzhikov, 1980) increased confusion. In our opinion, the crucial problem in contemporary taxonomy of Cyathostoma (including parasites of raptors) is poorly recognized morphological variability among/within species and disputable host specificity, resulting with large number of species with questionable validity. Thus, final confirmation of the validity of several $C$. (Hovorkonema) species, irrespective of evaluation of different morphological, morphometric and ecological data, required molecular methods. Unfortunately, up to the present, analyses of taxonomic and phylogenetic relationships among subfamily Syngaminae based on molecular markers are very scarce (Krone et al., 2007; Kanarek et al., 2013). So far, only Krone et al. (2007) analyzed molecular status and genetic diversity of nematode identified as Hovorkonema variegatum, collected from respiratory tracts of several birds species (including birds of prey) from Germany and based on the divergence of the compared ITS-2 sequences recognized existence of two distict groups of Cyathostoma (Hovorkonema) variegatum nematodes. On this base, the autors speculated about a occurrence of subspecies or a cryptic species, which are morphologically indistinguishable. In light of this, further studies regarding validity and molecular diversity of these nematodes occurring in birds of prey and owls are required.
Therefore, the main objective of the presented research was molecular identification and analyzes of SSU ribosomal gene diversity of $C$. (Hovorkonema) nematodes, collected from respiratory tracts of several species of raptors from Central Europe and North America. The obtained data are presented and discussed, and additionally, a hypothesis regarding validity of the avian $C$. (Hovorkonema) species is suggested.

\section{Material and Methods}

Sampling protocols, necropsy procedures and morphological identification

In spring of 2014, two subadult snowy owls Bubo scandiacus were found dead in Rhode Island, USA, and were transported to the Connecticut Veterinary Medical Diagnostic Laboratory (CVMDL). Necropsy revealed the presence of medium-sized, red nematodes in the air sacs and on the surface of the lung, identified visually as Cyathostoma sp. Worms were washed in tap water, fixed and stored in $70 \%$ ethanol. Additionally, during standard helminthological analysis of carcasses of birds of prey and owls, obtained from the Rescue Station for Animals, Bartošovice na Moravě, Czech Republic, nematodes initially identified as Cyathostoma sp. were found in air sacs of single Eurasian sparrowhawk Accipiter nisus, long-eared owl Asio otus and Eurasian eagle-owl Bubo bubo. The nematodes were washed in tap water, fixed in $70 \%$ ethanol and stored in the same medium for further examination.

Detailed analysis of sampled material, showed that all collected nematodes were adult females. Unfortunately, the lack of males prevented precise morphological determination to the species level. Voucher specimens have been deposited in the Polish Collection of Parasitic Helminths, Museum of Natural History, Wrocław University, Coll. No. 154285 (specimen ex Asio otus),154286 (specimen ex Bubo bubo), 154287 (specimen ex Accipiter nissus) and154288 (specimens ex Bubo scandiacus).

\section{Molecular analysis}

Material for the molecular analysis consisting of fragments (ca. $1 \mathrm{~cm}$ long) of the nematodes obtained from four host species (Accipiter nissus, Asio otus, Bubo bubo, B. scandiacus) was fixed as above and stored in $70 \%$ ethanol. Total genomic DNA was extracted using DNeasy Blood and Tissue Kit (Qiagen, Düsseldorf, Germany) according to the manufacturer's protocol. Amplification of ITS1-5.8S rDNA-ITS2 fragments was done using the following primers (van der Auwera et al., 1994) - NLF/NLR (5'-TTTGyACACACCGCCCGTCG-3'/5'-ATATGCTTAArTTCAGCGGGT-3') in the following thermocycling conditions: $95{ }^{\circ} \mathrm{C} / 3 \mathrm{~min}$. - initial denaturation; $95{ }^{\circ} \mathrm{C} / 30 \mathrm{sec}$., $48^{\circ} \mathrm{C} / 30$ sec., $72{ }^{\circ} \mathrm{C} / 45 \mathrm{sec} .-40$ cycles; $72^{\circ} \mathrm{C} / 7 \mathrm{~min}$ - final extension. The PCR reaction $(25 \mu \mathrm{l})$ was obtained: $4 \mu \mathrm{l}$ of genomic DNA, $10 \mathrm{mM}$ Tris- $\mathrm{HCl}, 50 \mathrm{mM} \mathrm{KCl}$, $1.5 \mathrm{mM} \mathrm{MgCl} 2,200 \mu \mathrm{M}$ of each dNTP, $150 \mathrm{pmol}$ of each primer and 2 units of Taq polymerase (EurX, Gdańsk, Poland). The amplification product was purified using QIAquick PCR purification kit 


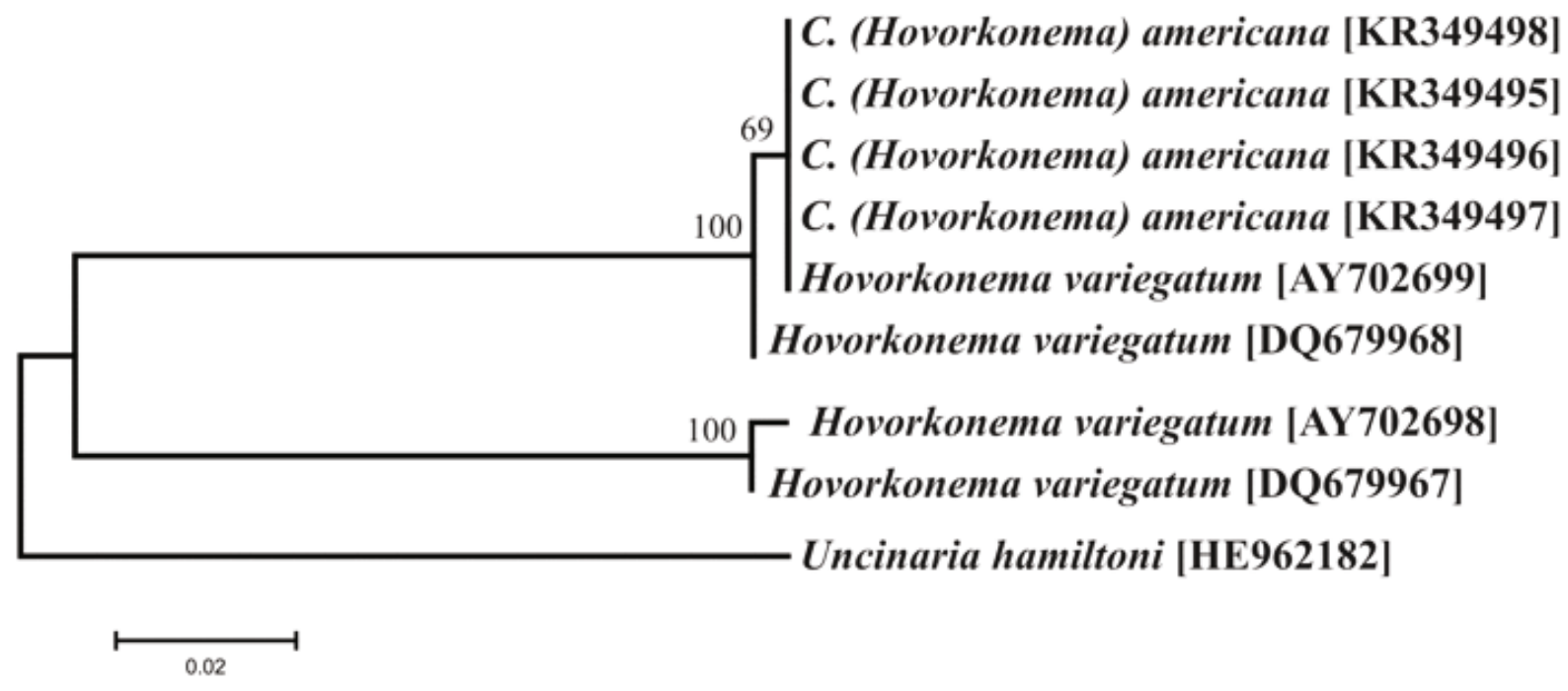

Fig. 1. Phylogenetic analysis of ITS1 and ITS2 sequences performed using Maximum Likelihood method, after fitting the best model (Tamura 3-parameter); bootstrap support calculated on basis of 500 replicates

(Qiagen, Düsseldorf, Germany) and sequenced in both directions (Genomed S.A., Poland). The obtained sequences were deposited in GenBank under following accession numbers KR349495KR349498.

In order to elucidate any homologies with previously deposited sequences in GenBank, a BLAST search (http://blast.ncbi.nlm.nih. gov/Blast.cgi) was conducted. The multiple alignment was done by the use of CLUSTAL W using MEGA 5.0 package (Tamura et al., 2011). Phylogenetic analysis of $C$. (Hovorkonema) was inferred using the Maximum Likelihood method.

\section{Results}

As a result of molecular analysis, four 929 - 934 bp long sequences of ITS complex (ITS1, 5.8S rDNA and ITS2) for C. (Hovorkonema) sp. were obtained. In the overlapping fragment (930 bp) all four sequences were identical and no genetic diversity was observed. In addition, the comparison of our sequences with those deposited in Gen Bank showed none (AY702699) or a single nucleotide difference (DQ679968) with the sequences described as "Hovorkonema variegatum". At the same time, our sequences showed quite large genetic variability with the two latter sequences of $H$. variegatum deposited under accession numbers: AY702698 (38 sites out of $297 \mathrm{bp}$ long alignment - 12.8\%) and DQ679967 (36/297 bp - 12.1\%). The ML phylogenetic analysis (based on ITS2) performed for our sequences and the sequences of $H$. variegatum deposited in Gen Bank showed the presence of two clades, one including six identical or almost identical (1 nucleotide difference) sequences of syngamid nematodes from birds of prey (KR349495-KR349495) and sequences previously deposited by Krone et al. (2007) (AY702699 and DQ679968) (Fig. 1). The sec- ond clade comprises two sequences (AY702698 and DQ679967) of $H$. variegatum.

\section{Discussion}

As mentioned previously, C. (Hovorkonema) nematodes detected in respiratory tracts of raptors have been identified usually as C. (Hovorkonema) americana Chapin, 1925; C (Hovorkonema) brodskii Sultanov, 1946 and C. (Hovorkonema) variegatum (Creplin, 1849). C. (Hovorkonema) americana was described by Chapin (1925), based on material collected from a host determined as the red-tailed hawk Buteo borealis (actually synonym of Buteo jamaicensis (Gmelin, 1788)) in Virginia, USA. Since description, this species has been detected in a wide range of birds of prey and owls and are considered by several authors (e.g., Borgsteede \& Okulewicz, 2001; Borgsteede et al., 2003; Sitko \& Okulewicz, 2010) as a rare, typical parasite of respiratory tracts of raptors in the Holarctic Region. However, Ryzhikov (1980) on the basis of experimental infection contested the validity of $C$. (Hovorkonema) americana and $C$. (Hovorkonema) brodskii and regarded both as synonym of $C$. (Hovorkonema) bronchialis (Mühling, 1884) widely recognized as typical parasite of Anseriformes. These conclusions were questioned by Borgsteede and Okulewicz (2001), who on the basis of morphological data and a critical review of existing literature data consider C. (Hovorkonema) americana as a valid taxa. Our results confirmed these statements: clearly demonstrating the existence of the same species of $C$. (Hovorkonema) in air sacs in birds of prey in Europe and North America - C. (Hovorkonema) americana. Obtained sequences clearly showed almost $100 \%$ homogeneity among nematodes sampled from birds of prey and owls from the Czech Republic, the snowy owl from North America and, 


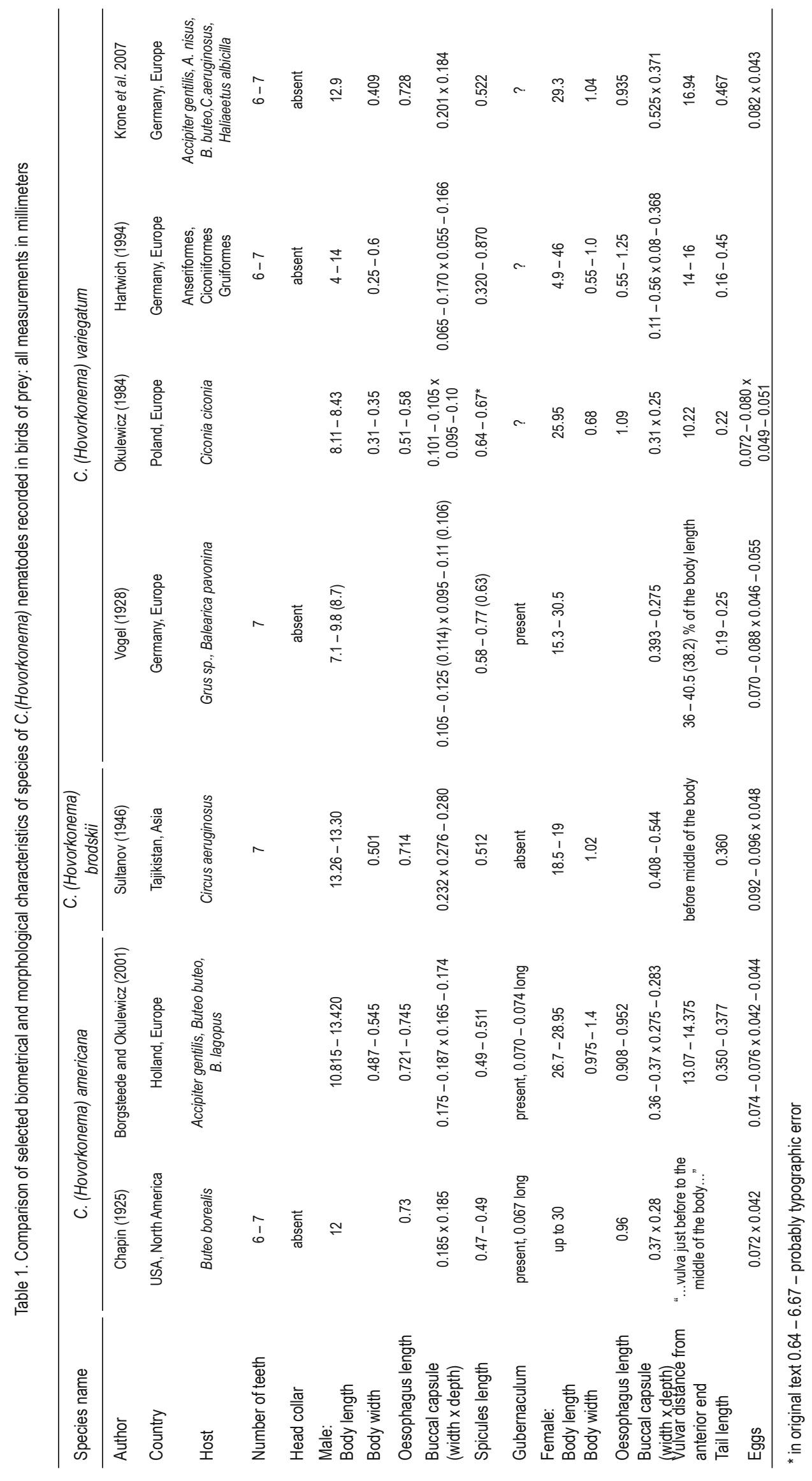


Table 2. Comparison of selected biometrical and morphological characteristics of $C$.(Hovorkonema) bronchialis (Mühling, 1884); all measurements in millimeters

\begin{tabular}{|c|c|c|c|c|}
\hline Author & Chapin (1925) & Griffiths et al. (1954) & Ryžikov and Zavadil (1958) & $\begin{array}{l}\text { Hernandez-Rodriguez et al. } \\
(1978)\end{array}$ \\
\hline Country & USA, North America & USA, North America & Ukraina, Europe & Espania, Europe \\
\hline Host & domestic geese, swans & domestic geese & Anser anser dom. & Anser anser \\
\hline Number of teeth & $?$ & $6-7$ & 7 & $?$ \\
\hline Head collar & absent & absent & weakly differentiated & $?$ \\
\hline $\begin{array}{l}\text { Male: } \\
\text { Body length }\end{array}$ & $4-5.8$ & $9.5-10$ & $9.5-10.7$ & $10-12$ \\
\hline Body width & & $0.25-0.328$ & $0.32-0.33$ & $0.367-0.402$ \\
\hline Oesophagus length & 0.35 & $0.560-0.570$ & & $0.630-0.690$ \\
\hline $\begin{array}{l}\text { Buccal capsule } \\
\text { (width } x \text { depth) }\end{array}$ & & $0.09-0.13 \times 0.14$ & $0.145-0.15 \times 0.109-0.132$ & $0.117-0.123 \times 0.091-0.105$ \\
\hline Spicules length & $0.51-0.62$ & $0.54-0.70$ & $0.58-0.72$ & $0.56-0.70$ \\
\hline Gubernaculum & $?$ & $?$ & present, 0.08 long & $?$ \\
\hline $\begin{array}{l}\text { Female: } \\
\text { Body length }\end{array}$ & $16-31$ & $16-26$ & $25-40$ & $22-28$ \\
\hline Body width & $0.7-0.9$ & $0.75-0.86$ & $0.62-0.83$ & $0.376-0.779$ \\
\hline Oesophagus length & & $1.0-1.14$ & $1.12-1.15$ & $1.210-1.350$ \\
\hline $\begin{array}{l}\text { Buccal capsule } \\
\text { (width } x \text { depth) }\end{array}$ & $0.325 \times 0.205$ & $0.33-0.42 \times 0.325$ & $0.41-0.56 \times 0.304-0.368$ & $0.262-0.297 \times 0.290-0.320$ \\
\hline $\begin{array}{l}\text { Vulvar distance from } \\
\text { anterior end }\end{array}$ & $\begin{array}{l}\text { "...vulva just in front to the } \\
\text { anterior end..." }\end{array}$ & $\begin{array}{l}\text { "...posterior part of the } \\
\text { anterior third of the body..." }\end{array}$ & $12-14.5 \mathrm{~mm}$ from anterior end & in first $1 / 3$ length of the body \\
\hline Tail length & $0.16-0.30$ & 0.075 & $0.272-0.336$ & $0.230-0.263$ \\
\hline Eggs & $0.074-0.083 \times 0.049-0.062$ & $0.068-0.085 \times 0.043-0.058$ & $0.073-0.083 \times 0.052-0.056$ & $0.082-0.086 \times 0.059-0.065$ \\
\hline
\end{tabular}

surprisingly, with only part of the sequences deposited by Krone et al. (2007) and described as "Hovorkonema variegatum" (Fig. 1).

In our opinion, sequences obtained by Krone et al. (2007) and identified as " $H$. variegatum", clearly consist of two molecularly distinct species and should be treated with considerable caution. Indisputably, as we mentioned previously, some of these represent C. (Hovorkonema) americana. But what about the others? C. (Hovorkonema) variegatum was described by Nathusius (1837) based on material collected from the black stork Ciconia nigra in Germany under the name Strongylus trachealis. Over a period of time, $C$. (Hovorkonema) variegatum was recognized as a typical parasite of storks and cranes (Vogel, 1928; Ryzhikov, 1949; Okulewicz, 1984), and also reported from the Indian peafowl, Pavo cristatus, in India (Ali, 1970). Moreover, this species was reported frequently in several species of birds of prey in Germany (Lierz et al., 1998; Krone, 2000; Krone et al., 2002; Lierz et al., 2002; Krone et al., 2007), Finland (Krone et al., 2006) and Spain (Sanmartín et al., 2004), but most of the cited authors do not give any morphological and morphometric data about these findings. According to detailed data, included only in the paper of Krone et al. (2007) Cyathostoma nematodes collected from Ciconiform, Falconiform and Gruiform birds were identified according to Hartwich (1994). However, Hartwich (1994), based on existing literature data, synonimised three species of $C$. (Hovorkonema): the author agreed with the hypothesis formulated by Ryzhikov (1980) and treated C. (Hovorkonema) americana as synonym of $C$. (Hovorkonema) bronchialis. Furthermore, according to Vogel (1928) and Ali (1970), Hartwich also regarded $C$. (Hovorkonema) bronchialis as a synonym of $C$. (Hovorkonema) variegatum. Thus, C. (Hovorkonema) variegatum sensu Hartwich (1994) consisted of three species: C. (Hovorkonema) americana, C. (Hovorkonema) bronchialis and C. (Hovorkonema) variegatum sensu stricto. In light of this, high level of morphometric variability given by Hartwich (1994) as key features for C. (Hovorkonema) variegatum, especially the spiculae length (range $0.320-0.870 \mathrm{~mm}$, Table 1) are not reliable. In several species of Cyathostoma spiculae length tends to be a constant feature, characterized by relatively low variability (Kanarek, 2009), and seems to be a good differentiating feature with key significance. According to available literature data (see Table 1), morphology of $C$. (Hovorkonema) americana and C. (Hovorkonema) variegatum are closely related, but not identical; despite almost identical structure of copulatory bursa (for details and comparison see e.g., Chapin, 1925; Vogel, 1928; Ali, 1970; Okulewicz, 1984; Borgsteede \& Okulewicz, 2001) C. (Hovorkonema) variegatum also possess distinctly longer spiculae $(0.58-0.77 \mathrm{~mm})$ than $C$. (Hovorkonema) americana (0.47 - $0.511 \mathrm{~mm}$ ) (Table 1). Other observed morphometric differences, such as dimensions of buccal capsule which is slightly larger in C. (Hovorkonema) variegatum (Table 1) are, in our 
opinion, not conclusive. What is important, nematodes identified as " $H$. variegatum" Krone et al. (2007) recorded not only in birds of prey (Accipiter gentilis, A. nissus, Buteo buteo, Circus aeruginosus, Haliaeethus albicilla), but also in common crane Grus grus, typical host of $C$. (Hovorkonema) variegatum sensu stricto. Unfortunately, sequences of ITS2 gene deposited by Krone et al. (2007) were not adequately described (lacking the name of the hosts), similar to the presented morphological data (lacking such basic facts as name of the hosts and range of the measurements). However, during preparation of the reviewed version of this manuscript the sequence data of Krone et al. (2007) have been updated (last modification $9^{\text {th }}$ of September 2015). Thus, in the light of presented facts, we are convinced, that some sequences deposited in GenBank as " $H$. variegatum" by Krone et al. (2007) are clearly distinct from sequences obtained in the present work of $C$. (Hovorkonema) americana and represent sequences of $C$. (Hovorkonema) variegatum sensu stricto (DQ679967 and AY702698). In our opinion C. (Hovorkonema) americana (typical parasites of tracheae and air sacs of raptors) and C. (Hovorkonema) variegatum (typical parasites of tracheae of cranes and storks) are valid, molecularly and morphologically distinct species. Although, we cannot exclude the possibility that $C$. (Hovorkonema) variegatum can accidentally parasitize birds of prey and owls (e.g. DQ679967 - Accipiter nisus and AY702698 - Buteo buteo) but this results do not confirm that this phenomenon is common and this issue requires further study. On the other hand, literature data clearly showed, that $C$. (Hovorkonema) variegatum in typical hosts, such as storks and cranes occurs exclusively in trachea (Vogel, 1928; Okulewicz, 1984), while C. (Hovorkonema) americana in raptors were recorded mainly in air sacs, less frequently in tracheae (Hunter et al., 1993; Borgsteede \& Okulewicz, 2001; Krone et al., 2007), but this issue regarding further, detailed analysis.

Another interesting issue is the validity of $C$. (Hovorkonema) bronchialis, a species reported mainly in geese, but also detected in Casuariiformes. Some authors (Ryžikov \& Zavadil, 1958; Ali, 1970; Baruš et al., 1978) recognized C. (Hovorkonema) boularti (Megnin, 1884) and C. (Hovorkonema) bronchialis as synonym of $C$. (Hovorkonema) variegatum. However, Borgsteede and Okulewicz (2001) recognized C. (Hovorkonema) bronchialis as a valid species. Based on literature data (e.g., Griffiths et al., 1954; Ryžikov \& Zavadil, 1958; Hernandez-Rodriguez et al., 1975) the structure of copulatory bursa, morphology and morphometry of $C$. (Hovorkonema) bronchialis, especially spiculae length are closely related to $C$. (Hovorkonema) variegatum (for details and comparison see e.g., Chapin, 1925; Vogel, 1928; Ryžikov \& Zavadil, 1958 and Tables 1 and 2). However, spiculae length provided by Chapin (1925) for $C$. (Hovorkonema) bronchialis $(0.51-0.62 \mathrm{~mm})$, differ slightly from measurements provided by Griffiths et al. (1954) (0.54 - 0.70 $\mathrm{mm})$, Ryžikov and Zavadil (1958) $(0.58-0.72 \mathrm{~mm})$ and Hernandez-Rodriguez et al. (1975) $(0.56-0.70 \mathrm{~mm}$ ) (Table 2). Based on this, it is quite possible that $C$. (Hovorkonema) bronchialis is an synonym of $C$. (Hovorkonema) variegatum, but this issue requires further research based on detailed molecular and morphological analysis of material collected from typical hosts (Anseriformes). The last species of $C$. (Hovorkonema) recorded in birds of prey, C. (Hovorkonema) brodskii was described on the basis of nematodes collected from the Western marsh-harrier Circus aeruginosus, sampled near Tashkent, Uzbekistan, Central Asia (Sultanov, 1946) and has not been recorded since. Therefore its validity is still doubtful. In fact, C. (Hovorkonema) brodskii and C. (Hovorkonema) americana are almost identical, except slightly smaller body dimensions, larger eggs and buccal capsule in C. (Hovorkonema) brodskii (Table 1), but in our opinion these differences are not significant. What is important, spicuale length in C. (Hovorkonema) brodskii and $C$. (Hovorkonema) americana are the same; the only one, well-articulated differentiating feature is absence of gubernaculum in C. (Hovorkonema) brodskii (Table 1). Among Strongyloidea, absence/presence of gubernaculum is recognized as an important feature with significant taxonomic implications e.g., Ali (1970) based his arrangement of subfamily Cyathostominae on the presence/absence of gubernaculum. However, this structure (when it occurs) in Cyathostoma is small, delicate and very easy to overlook, especially in well-cleared material. In fact, it is difficult to resolve whether differences in absence/presence of gubernaculum in morphologically close related species of $C$. (Hovorkonema) are key differentiating features, or whether they result from variability among specimens or misapprehension in the original descriptions. On the other hand, two $C$. (Cyathostoma) species occurring in respiratory tract of fish-eating avian hosts, $C$. (Cyathostoma) phenisci Baudet, 1937 and C. (Cyathostoma) verrucosum Hovorka \& Macko, 1959 are almost identical, with the exception of the presence of gubernaculum in C. (Cyathostoma) verrucosum; however, molecular analysis showed the identical nature of both species (Kanarek et al., 2013). On this basis, we tend to recognize C. (Hovorkonema) brodskii as a synonym of $C$. (Hovorkonema) americana.

The present work shows that in the tracheae, bronchii and air sacs in analyzed birds of prey and owls from Europe and North America, only one species of $C$. (Hovorkonema) occurs, $C$. (Hovorkonema) americana. However, incidental occurrence of other $C$. (Hovorkonema) species, typical for other groups of avian hosts, is possible. The result obtained also emphasizes the necessity for careful and critical interpretation of the existing data, regarding morphology and systematics of both subgenera among Cyathostoma. Moreover, this demonstrates the need to use both morphological and molecular methods in the contemporary ecology and systematics of syngamid nematodes.

\section{References}

ALı, M.M. (1970): A review and revision of the subfamily Cyathostominae Nicoll, 1927 (Nematoda, Syngamidae). Acta Parasitol. Pol., 17: 237 - 246

Baruš, V., TenORA, F. (1972): Notes on the systematics and taxo- 
nomy of the nematodes belonging to the family Syngamidae Leiper, 1912. Acta Univ. Agric. Brno, 20: 275 - 286

Baruš, V., Sergeeva, T.P., Sonin, M.D., Ryzhikov, K.M. (1978): Nematoda. In: RYŠAvÝ, B., RYZHIKov K. M. (Eds) Helminths of fish-eating birds of the Palearctic region. Moscow, Prague: USSR Academy of Sciences, Helminthological Laboratory Czechoslovak Academy of Sciences, Institute of Parasitology, 318 pp.

BLANCHARD, E. (1849): Investigations on the organization of Vermes. Ann. Sci. Nat. Zool,. 3: 106 - 202 (In French)

Borgsteede, F.H.M., Okulewicz, A. (2001): Justification of the species Cyathostoma (Hovorkonema) americana (Chapin, 1925) (Syngamidae-Nematoda). Helminthologia, 38: 151 - 154

Borgsteede, F.H.M., Okulewicz, A., Zoun, P.E.F., Okulewicz, J. (2003): The helminth fauna of birds of prey (Accipitriformes, Falconiformes and Strigiformes) in the Netherlands. Acta Parasitol., 48: $200-207$

ChapIN E.A. (1925): Review of the nematode genera Syngamus Sieb. and Cyathostoma E. Blanch. J. Agric. Res., 30: 557 - 570 Fernando, M.A., BARTA, J.R. (2008): Tracheal worms. In: AtKInSon, C.T., Thomas, N.J., Hunter, D.B. (Eds) Parasitic diseases of wild birds. John Wiley \& Sons, pp. $343-354$

Griffiths, H.J., LeARy, R.M., Fenstermacher, R. (1954): A new record for gapeworm (Cyathostoma bronchialis) infection of domestic geese in North America. Am. J. Vet. Res., 15: 298 - 299.

Hartwich, G. (1994): The wildlife of Germany. Part 68. Nematoda II. Strongylida: Strongyloidea und Ancylostomatoidea. Jena, Gustav Fisher Verlag, 157 pp. (In German)

Hernandez-Rodriguez, S., Calerto-Carretero, R., Becerra-Martel, C., Dominguez de Tena, M., Moreno-Montañez, T., Martinez-Gomez, F., BARASONA-MatA, J. (1975): Cyathostoma bronchialis (Mühling, 1884) Chapin, 1925 (Nematoda: Syngamidae) in Anser anser, first record in Spain. Rev. Iber. Parasitol., 35: 367 - 371 (In Spanish)

HovorKa, J., MAcko, J. (1959): Calcaronema gen. nov. a new genus of the subfamily Cyathostominae Nicoll, 1927 (Syngamidae Leiper, 1912) and the description of the new species $C$. trifurcatum sp. n. and C. verrucosum sp. n. Helminthologia, 1: $103-112$

Hunter, D.B., McKeever, K., Bartlett, C. (1993): Cyathostoma infection in screech owls, saw-whet owls and burrowings owls in southern Ontario. In: Redig, R. T., Cooper, R. T., Remple, J. D., Hunter, D.B. (Eds) Raptor Biomedicine. Minneapolis, University of Minnesota Press, pp. $54-56$

KanAREK, G. (2009): The occurrence of Cyathostoma (Cyathostoma) microspiculum (Skrjabin, 1913) (Nematoda: Syngamidae) in the great cormorant [Phalacrocorax carbo (L., 1758)] in north-eastern Poland. J. Helminthol., 83: 391 - 398. DOI: 10.1017I S0022149X09990307

Kanarek, G., Horne, E., Zaleśny, G. (2013): Cyathostoma (Cyathostoma) phenisci Baudet, 1937 (Nematoda: Syngamidae), a parasite of respiratory tract of African penguin Spheniscus demersus: morphological and molecular characterisation with some ecological and veterinary notes. Parasitol. Int., 62: 416 - 422. DOI:10.1016/j.parint.2013.05.002
KRONE, O. (2000): Endoparasites in free ranging birds of prey in Germany. In: LumeIJ, J.T., Remple, J.D., Reding, P.T., Lierz, M., COOPER, J.E. (Eds) Raptor Biomedicine III, including bibliography of diseases of birds of prey. Lake Worth, Zoological Education Network, pp. 101 - 116

Krone, O., Langgemach, T., Sömmer, P., Kenntner, N. (2002): Diseases and causes of death of white-tailed eagles (Haliaeetus albicilla) in Germany. Corax, 19: 102 - 108 (In German)

Krone, O., Friedrich, D., Honisch, M. (2007): Specific status and pathogenicity of syngamid nematodes in bird species (Ciconiformes, Falconiformes, Gruiformes) from Germany. J. Helminthol., 81: $67-73$

Krone, O., Stuenberg, T., Kenntner, N., Tataruch, F., Kolvusaari, J., NuUJA, I. (2006): Mortality factors, helminth burden and contaminant residues in white-tailed sea eagles (Haliaeetus albicilla) from Finland. Ambio, 35: 98 - 104

Lavoie, M., Mikaelian, I., Sterner, M., Villeneuve, A., Fitzgerald, G., Mclaughin, J.D., LaiR, S., Martineau, D. (1999): Respiratory nematodiases in raptors in Quebec. J. Wildl. Dis., 35: $375-380$

Lierz, M., Schuster, R., Ehrlein, J., Göbeln, T. (1998): Findings of Hovorkonema variegatum in northern goshawk Accipiter gentilis. Kleintierpraxis, 43: 43 - 46 (in German)

Lierz, M., Göbel, T., Schuster, R. (2002): Research on the occurrence of parasites in native birds of prey and owls. Berl. Münch. Tierärztl. Wschr., 115: 43 - 52 (In German)

LENGY, J. (1969): Notes on the classification of Syngamidae (Nematoda) with new data on some of the species. Israel J. Zool., 18: $9-23$

LICHTENFELS J.R. (1980): Keys to the genera of the superfamily Strongyloidea. In: Anderson R. C., Chabaud, A. G., Willmott, S. (Eds) CIH Keys to the nematode parasites of vertebrates, No.7. Farnham Royal. Bucks, UK, Commonwealth Agricultural Bureaux, 41 pp.

Mumcuoglu, Y., Müller, R. (1974): Parasitic mites and worms as the cause of death of eagle owl Bubo bubo. Ornit. Beob., 71: 289 - 292 (In German)

Nathusius, H. (1837): Some intestinal worms from black stork. Arch. Naturgesch., 3: 52 - 65 (In German)

Okulewicz, A. (1984): Cyathostoma variegatum (Creplin, 1849) Chapin, 1925 and Cyathostoma lari Blanchard, 1849 (Nematoda, Syngamidae) in Poland. Wiad. Parazytol., 30: 53 - 56

Ryzhikov, K.M. (1949): Syngamidae of domestic and wild animals. In: SKRYABIN, K. I. (Ed) Essentials of nematodology. I. Leningrad, Moskva, 164 pp. (In Russian)

RYZHIKov, K.M. (1967): Revision of the system of Syngamidae. Prob. Parazitol. Tez. Dokl. V Nauchnoj Konf. Ukr. Vesp. Nauchnoj Obsch. Parazitol. Kiev, 184 - 187 (In Russian)

RYzHIKov, K.M. (1980): The biology of a nematode Cyathostoma bronchialis (Syngamidae: Strongylata). Helminthologia, 17: 241 244

RYŽIKOV, K.M., ZAVADIL, R. (1958): On the identity of species of the genus Cyathostoma collected from ostrich. Acta Univ. Agric. Silvic. Brno, 2: 125 - 132 (In Czech) 
Sanmartín, M.L., Álvarez, F., Barreiro, G., Leiro, J. (2004): Helminth fauna of Falconiform and Strigiform birds of prey in Galicia, Nortwestern Spain. Parasitol. Res., 92: 255 - 263. DOI 10.1007/ s00436-003-1042-z

SIMPSON, V.R., HARRIS, E.A. (1992): Cyathostoma lari (Nematoda) infection in birds of prey. J. Zool., 227: 655 - 659. DOI: 10.1111/ j.1469-7998.1992.tb04421.x

SitKo, J., OKuLEWICZ, A. (2010): Checklist of the nematodes in birds in the Czech Republic and the Slovak Republic. Prerov, Comenius Museum, 104 pp.

SkRYABIN, K.I. (1915): Nematodes of birds of Turkestan. Ezh. Zoolog. Muz., 20: 457 - 557 (In Russian)

Sultanov, M. (1946): Nematodes of birds of prey. Akad. Nauk Uzbek. SSR, Trudy Sekt. Zool., 86 - 105 (In Russian)

Tamura, K., Peterson, D., Peterson, N., Stecher, G., Nei, M., KuMAR, S. (2011): MEGA5: molecular evolutionary genetics analysing maximum likelihood, evolutionary distance, and maximum parsimony methods. Mol. Biol. Evol., 28: 2731 - 2739. DOI: 10.1093/ molbev/msr121
Turemuratov, A. (1963): Syngamidae of Pelecaniform birds of Aral Sea with comments on the structure of this nematode family. Vest. Karakal. Fil. Akad. Uzb. SSR, 3: 45 - 50 (In Russian)

van der Auwera, G., Chapelle, S., de Wachter, R. (1994): Structure of the large ribosomal subunit RNA of Phytophtora megasperma, and phylogeny of the oomycetes. FEBS Letters, 338: $133-136$. DOI: 10.1016/0014-5793(94)80350-1

Vaughan-Higgins, R., Murphy, S., Carter, I., Pocknell, A., Harris, E., SAInsbury, T. (2013): Fatal epicarditis in a hen harrier (Circus cyaneus) a red listed bird of high conservation concern in Britain associated with Cyathostoma species and Eschericha coli infection. Vet. Rec., DOI: 10.1136/vr. 101476

VogeL, H. (1928): About biology and morphology of Cyathostoma variegatum (Creplin, 1849) [Syngamus variegatum]. Z. Infektionskrankh., 34: 97 - 117 (In German)

YamagutI, S. (1961): Systema helmintum. Volume III: The Nematodes of Vertebrates. Interscience Publishers Inc., New York, $679 \mathrm{pp}$. 